\title{
Travel, Technology, and Theory: The Aesthetics of Ichthyology during the Second Scientific Revolution
}

Claudia Kreklau

\begin{abstract}
By investigating the ichthyology of "foreign fishes" in the Age of Exploration and printing developments before the camera, aquariums, and Darwin, this article shows that aesthetic theory and romanticism informed and inflected ichthyology during its rapid development 1780-1830. It builds on the mutual constitution of art and science during the Second Scientific Revolution and aesthetic ways of seeing that treated beauty as an indicator of scientific truth that preceded scientific objectivity, and demonstrates that by 1839, ichthyologists operated in an ontological framework that integrated fishes into nature and located the scientific viewer in a world of natural beauty.
\end{abstract}

In 1790, Immanuel Kant noted how "horrible" the sight was of "the vast ocean heaved up by storms."1 American writer and Romantic Henry David Thoreau wrote as late as 1864 that " $[t]$ he ocean is a wilderness reaching round the globe, wilder than a Bengal jungle, and fuller of monsters."2 Yet in 1825, ichthyologist William Greatheed Lewis compared the "lustre" of the mackerel with that of a "diamond," and the "crescent" on the Gilt head's cranium with a "gold-colored" moon. ${ }^{3}$ Between 1780 and 1830, ichthyologic understandings of fishes changed profoundly. This article shows how ichthyologists and their artistic collaborators brought new scientific ways of seeing to bear on their study of "foreign fishes" ${ }^{4}$ and portrayed them as aesthetically pleasing portions of a sublime 
natural world. "Truth," Daston and Galison remind us, "came before and remains distinct from objectivity." ${ }^{5}$ During the "Second Scientific Revolution," this period of rapid development similar to the first Scientific Revolution that preceded it, the truth of fishes was often aesthetic. " ${ }^{\text {"Drawing from nature" }}{ }^{77}$ here meant seeing nature in a particular way: it was an "act of aesthetic appreciation, selection, and accentuation. ... images were made to serve the ideal of truth—and often beauty along with truth." ${ }^{\prime 8}$ Ichthyologists benefited in this era of significant scientific activity from travel to foreign shores and new printing technologies, and especially, from a visual appreciation of what they termed "foreign fishes" guided by aesthetic theory and inflected by romanticism. Thus, by 1839 , a naturalist like William Swainson could write that the scientist's job was to "invest general truths with a sort of majesty, as well as of beauty; so that... abstract principles come forth ... into the light, stand out with greater distinctness before the mind." Ichthyologists like Swainson made the case that ichthyologists' ability to see beauty was a way of accessing truth, displaying beauty a method for making truth more visible, and thus that both were key to scientific investigation and communication.

Ichthyology was slow to develop when compared to other pursuits of natural history. Collectors for cabinets of curiosities drew up inventories of nature with the seventeenth-century Museum Wormianum and Louis XIII's 1635 Cabinet du Roi which prioritized visually impressive megafauna and aesthetically pleasing items that kept and aged well. ${ }^{10}$ Dried and preserved fishes that lost their luster in death, rotted after a few decades, and attracted pests, were not a sound investment for these exhibitions meant to communicate a sovereign's "status." ${ }^{11}$ A fish's place was therefore the naturalist's "laboratory" - to use Otis" term for their workplaces—a crate in a natural history 
museum's attic. For a long time, there was little interest or financial motivation in pushing ichthyologic research forward. ${ }^{12}$ Swainson noted as late as 1840 that ' $[\mathrm{t}]$ he impossibility of preserving the beautiful but evanescent colours of fish...and the unsightly appearance they generally present, whether in spirits or in a dried state, prevents these animals from being much attended by most scholars." 13

Given the lag of ichthyology behind other sub-disciplines of natural history, and the mass of information travel brought to Europe in the era of exploration and new printing technologies, ichthyology advanced quickly during the Second Scientific Revolution. Ichthyologic publications experienced an increase between 1738 and 1856, with authors such as Linnaeus (1738), Bloch (1782-95), Lacépède (1798-1803), Pinnock (1825), Rüppel (1828), Cuvier (1817-1830, 1834), Jardine (1835), Bennett (1830), Richardson (1842), Breevort (1856), and Bleeker (1862-1877), followed by a dip until after the First World War. The rapid development of ichthyology in this time makes the topic a small laboratory of heightened activity, involving more than just specialists, from fellow crew-members to native experts such as fishers and market-vendors, and leading to the simultaneous inventorization and study of nature beyond the confines of professionalization so illustrative of this period. ${ }^{14}$

Artistic representation, printing, and travel also did their part to facilitate ichthyologic advancement. Art was part of the scientific enterprise. Captains like James Cook took naturalists and artists along "to draw new flora and fauna" in a lifelike manner on their travels. ${ }^{15}$ The printing industry, in turn, catered to the demand for "colour printing" that could produce a large number of "identical...copies of a scientific diagram or illustration"16 in the early nineteenth century through such innovations as William 
Congreve's relief-block color printing in 1819, George Baxter's color xylographies in 1835, Charles Knight's "illuminated printing” in color patented in England in 1838, and Godefroy Engelmann's chromolithographie in 1837 in France. ${ }^{17}$ Yet, the greatest advancement was the new scientific ways of seeing. Aesthetic theory inflected by romanticism informed scientific ways of seeing between 1780 and 1830 and led ichthyologists to visually experience fish as beautiful—a significant difference to previous decades' ways of scientific seeing, as German thinkers in particular reconciled truth with nature and reformed the former skepticism towards matter that had dominated in European thought since Aquinas and Descartes. ${ }^{18}$ This laid the groundwork for aesthetic descriptions, naming strategies of foreign fishes, and their aesthetic visual representation in ways that previous ichthyologic works had failed to accomplish. Using beauty as an indicator of truth, ways of seeing during the Second Scientific Revolution located the ichthyologist in a sublime ontology, wherein their aesthetic appreciation of beauty formed part of the human subject's a priori. While Daston and Galison's milestone Objectivity explicitly excludes romanticism from their analysis of preobjectivity scientific seeing, this article argues that at least in ichthyology, Romanticism influenced aesthetic scientific study. ${ }^{19}$ This differentiation contributes to a growing body of scholarship that has recognized the contributions of romantic science to natural history. ${ }^{20}$

The following analysis of ichthyologic studies of foreign fishes during the Second Scientific Revolution - consisting of museum and laboratory collecting, Linnaean taxonomization, and exploration, and before the "invention of the aquarium," ${ }^{21}$ the camera, scientific objectivity, and Darwinian evolutionary theory ${ }^{22}$-draws our attention 
to the artificiality of the dividing line between art and science in practice, the value of artscience interaction in the pursuit of scientific truth, and the knowledge gained through pre-objective ways of scientific seeing, as guided by aesthetic theory, in a transnational enterprise to explore nature during the Second Scientific Revolution. ${ }^{23}$ While this article discusses mostly “foreign fishes"—using Bloch's turn of phrase—often meaning nonEuropean salt-water marine vertebrates, it prioritizes ways of seeing above other potential discussions, such as orientalism, the gendering of nature, and taxonomic classification, for the key role vision played in this era's scientific epistemology. ${ }^{24}$

Part one shows how ichthyologic collecting methods consisted of harvesting carcasses off foreign beaches, leaving gentleman naturalists hesitant to engage with moribund specimens. ${ }^{25}$ The context of collection influenced ichthyologists' experience and perpetuated a negative image of the sea, as explored by Rozwadowski. ${ }^{26}$ Part two turns to consider preservation methods, and details how ichthyologists fused foreign fishes into the European seascape. The examination of dried or "stuffed" fish, and specimens preserved in alcohol, did not alter the idea of the sea, but confirmed it, while the naturalists' ways of "seeing” fishes' beauty remained limited. ${ }^{27}$ Part three assesses the role of technology in printing and the reproduction of images, arguing that a larger shift was necessary than technology or travel alone could achieve for ichthyologists and their collaborators to see, taxonomize, describe, and represent fish as aesthetic creatures, integrated into a sublime natural world.

Collection: Gentlemen studying Fish out of Water 
From early modern times until far into the eighteenth century, fish suffered from a consistently negative image in European scientific literature. Rozwadowski's work on deep sea exploration has shown that negative experiences connected to the sea-such as loss and powerlessness in the face of natural forces-led Europeans to imagine the sea as a site of death. Sailors went overboard and missing, while "seasickness was a...constant reminder that the ocean was not a natural human environment." ${ }^{28}$ For its inhabitants, the same applied: the famous naturalists of the early modern period discussed sea creatures in the register of sea monsters. ${ }^{29}$ Even as late as 1825 , William Greathead Lewis' Catechism of Ichthyology argued Uranoscapes "subsist on worms, small fish, testaceous [sic] and crustaceous animals; and their powers of digestion are so strong as to dissolve the greatest part of the shells which they swallow." ${ }^{30}$ Similarly, the eel "is extremely voracious, and very destructive to the young fry of fishes. No other fish is capable of living so long out of the water, nor is any so tenacious of life." ${ }^{31}$ Equating their senses with sensibilities, Lewis argued that:

the faculties of fishes are greatly inferior to those of land animals. The sense of feeling, so exquisite in men and quadrupeds, can be but imperfect in fish. The sense of smell they enjoy in very limited degree; in that of taste, they appear very defective, and their hearing is still more imperfect. Fishes, however, possess the sense of sight in tolerable perfection, because this is essentially necessary to their preservation. ${ }^{32}$ 
Georg Wilhelm Friedrich Hegel agreed in his Philosophy of Nature that "Fish...simply abandon their young, and right from the start, show no concern for them whatever." 33 "A craving desire for food seems to be the ruling principle of all their actions and motions. ...[T] he stronger [prey] on the weaker, ${ }^{, 34}$ wrote educational author William Pinnock, and "no indulgence can gratify their rapacity." ${ }^{35}$ These creatures could live to be several hundred years old and led a dark, deaf, dumb, and unfeeling existence, which fit the eighteenth- and early nineteenth-century understanding of monsters. ${ }^{36}$ Pinnock concluded, "the life of fishes, from the smallest to the greatest, is but one continual scene of hostility, violence, and evasion. ${ }^{.37}$

Fear, disgust, and poor return on investment hampered the development of ichthyology when compared with the natural historical collection and study of their landbased counterparts. ${ }^{38}$ Travelers neither swam, nor studied live specimens, but instead interacted exclusively with dead fish until the late eighteenth century. John Stanley Gardiner, best known for his extensive expeditions into the Indian Ocean, was one of the very first naturalists to study coral reef fauna by diving in the early twentieth century ${ }^{39} \mathrm{It}$ was not until the 1970s, with Jacques Cousteau's snorkeling in the Caribbean, that naturalists began observing living fish in their natural habitat as a rule for the purpose of analyzing their behavior. Travelers in the eighteenth century prioritized filling royal cabinets of curiosities with fashionable and long-lasting items as returns on investment towards their zoological research and expeditions. ${ }^{40}$ From the seventeenth century, filling cabinets of curiosities functioned as a courtly "arms race," tied to exploration, possession, and imperial projects between the monarchs of the Old World. ${ }^{41} \mathrm{~A}$ dried fish with its odor, the odd, dry worm that fell dead out of its body (a common problem for collectors 
who worked in warm climates), or else the live worms in it, plus the need to beat off moths that fed on the specimen's brittle remains - did not qualify as a prestigious addition, attractive curiosity, or a wonder of nature. ${ }^{42}$

A gentlemanly culture of research further contributed to the persistence of fish's negative image. ${ }^{43}$ Naturalists' activity was made possible by either independent means, denoting that the naturalist was at least an untitled gentleman, if not more highly ranked, or else the educated second or third son of gentlemen with wealthy families capable of sustaining them and funding their activity. Francis Willoughby and John Ray, to name the authors of the History of Fishes, exemplify these cases respectively. ${ }^{44}$ A gentleman, in turn, would not handle live fish or dirty his hands with the "slimy glutinous fluid" in which the fish were covered ${ }^{45}$ Gentlemen compiled the collections, but they commanded cohorts of students and subordinates to carry out their sampling. ${ }^{46}$

The study of fish did not include swimming or the observation of fish in water. More often than not, naturalists outsourced collecting to fishermen, or else, "ramble[d] on the coast ${ }^{\$ 47}$ somewhere near their ship. Particularly in the early phases of the gentlemanly voyages, progress was slow and findings slim. Alexander von Humboldt, passionate botanist of the American jungles and adventurous explorer, complained about his sea-interested counterparts and their seeming lack of engagement with their element of study: "they never ventured far from their ship...their researches were confined to islands and coasts, and...they were interested only in the mechanical tasks of collecting and listing. ${ }^{\circledR 48}$ In a 1785 letter from surgeon Everard Home to collector John Hunter, the former narrated the discovery of a new species in the West Indies and described how the organism was "brought to the naturalist's attention" ${ }^{49}$ when "[ $[$ ]he animal was first 
observed by Captain Hendies, the officer commanding Fort Charles, in looking for shells which were thrown up in great numbers from the bottom of the harbour" ${ }^{250}$ due to a hurricane having stirred up the sea the preceding night. Similarly, Cuvier in his essay on the history of ichthyology mentions that the naturalists Banks, Solander and the two Forsters "collected many fishes on the very productive beaches of the [East] Indian Archipelago and South Pacific and had several of them drawn by Parkinson," while Sonerat's fish had been "gathered" on the coast. ${ }^{51}$ Note that Cuvier calls the beaches of the Pacific "productive", rather than the ocean itself.

As a result, traveling and non-traveling naturalists had an understanding of fish, quite literally, out of water, through almost exclusive contact with dead or dying fish, the negative, or even pungent experience of which possibly influenced their views of the specimen's character. Several ichthyologic works feature as their frontispiece illustrations of stranded fish, fish caught in nets or represented as alive and sitting on a beach, such as in the depiction of a "Cape armourhead" in a work by William Jardine (1784-1843) from 1835 (Figure 1), mimicking the context in the way they were collected. ${ }^{52}$ The conception of their character was thus based on, to use modern language, a skewed sample of a fish's behavior, since naturalists only knew specimens from their behavior when close to death. 


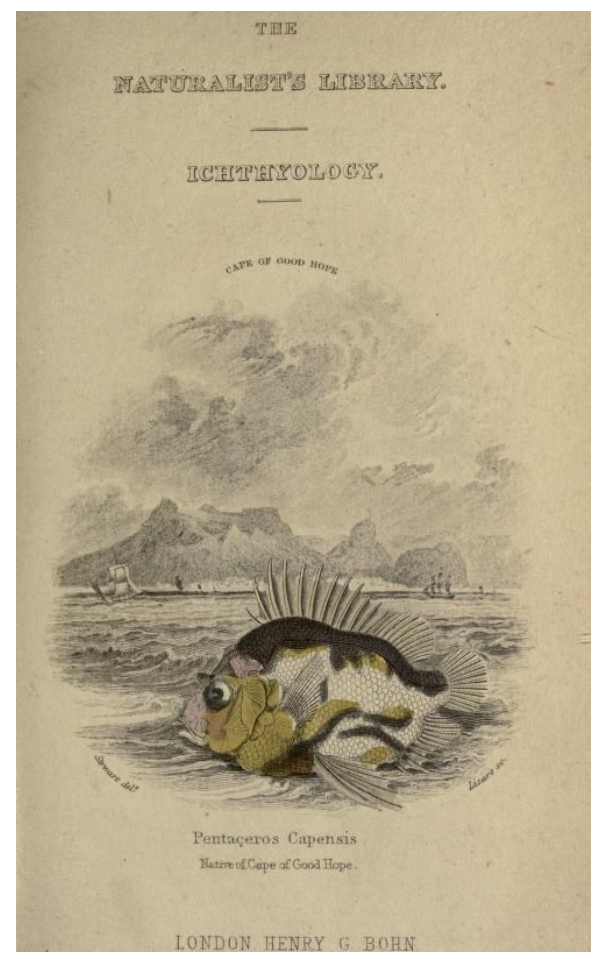

Figure 1. Jardine's stranded Pentaceros capensis. William Jardine, The Naturalist Library, Vol 1. Ichthyology, (Edinburgh: W.H.Lizars, 1835). Public Domain.

If naturalists did interact with fish, death constituted a recurring image in naturalist—fish interactions and conceptualizations. The "weever," Lewis insisted, was a poisonous fish and the "wounds inflicted by the spines ... extremely painful, attended with a burning, a pungent shooting...from a sort of venom infused into the wound." 53 The noxious "seadragon," in turn, buried itself in the sand and "if trod on, str[uck] with great force." ${ }^{54}$ Therefore, the Forsters, father Johann Reinhold and his son George travelling in Tahiti, were not in a hurry to kill the devilfish that their company caught, and did not wish to run the risk of its sting. Instead, they may have let it suffocate, and certainly waited until the next day, when it was unquestionably dead, to draw it. ${ }^{55}$ The fear of the monster led to a perpetuation of the fish's negative image even in the stages of Enlightenment naturalists' research. 
Alternatively, gentleman scholars would study drawings of fish, rather than real samples, up until the late eighteenth century. Schneider, for example, used descriptions of fish for his edition of Bloch's Ichthyologiae — a manner of working still valued during the latter half of the eighteenth century when the Royal Library of Berlin bought them. Similarly, the Count of Lacépède drew on his teacher Buffon's notes dating from the mid-eighteenth century. ${ }^{56}$ By the turn of the nineteenth century, using descriptions exclusively for work decreased in popularity, eventually to be discarded. Baron Cuvier criticized Lacépède for having "only rough drafts of the descriptions, which were not in good order and not always possible to match with the figures" ${ }^{\prime 57}$ available for the compilation of his work, thus limiting the quality. Right until Cuvier's own time, however, it was not the norm that naturalists should travel. Key naturalists and classifiers of fish, such as Carl von Linné (1707-1778), Markus Elieser Bloch (1723-1799), and Cuvier himself (1769-1832) were not adventurous voyagers, but were instead the centers of wider networks that spanned the globe, and brought bounties of specimen back home to their laboratories.

\section{Preservation and the (In)Ability to "See"}

The form in which samples reached Linnaeus, Bloch, and Cuvier's laboratories at the core of collecting networks, in turn, was dried or preserved in alcohol. We might compare "drying," popular until the early nineteenth century, to the practice of taxidermy. ${ }^{58}$ Preservers gutted the fish, removed all the bones but the skull, filled the skin with sand to keep the shape of the fish, and left it to dry. After removing the sand, they filled it with cotton, and sewed it closed to imitate the original form. ${ }^{59}$ These dried 
creatures were fit for travel and frequented the cabinets and museums in Europe ${ }^{60} \mathrm{Carl}$ von Linné, father of taxonomy, studied the first clownfish in Europe in such a format in 1758: the Amphiprion polymnus. ${ }^{61}$ Alternatively, collectors submerged the specimen in alcohol, preferably "spirit of wine", or "the common rum of the West Indies,"- anything but "common English gin," Swainson insisted: gin, "so much adulterated, ... is quite unfit... its only qualities seem those of destroying living men and dead animals." ${ }^{\prime 62}$ Many foreign fish samples reached European shores in flasks. ${ }^{63}$ Bloch, called the "founder of modern ichthyology," ${ }^{, 64}$ held a private collection of over a thousand preserved specimens of fish, now the oldest part of the Museum of Natural History's ichthyologic collection in Berlin. $^{65}$

The use of dried or preserved fish limited the naturalists' ability to "see" beauty in their specimen. In aesthetic representations of fish, the ichthyologist and their artists either hardly differentiated between the "native" and "foreign," or else limited the use of silver and gold in the hand-coloration of copperplate prints of "native" fish ${ }^{66}{ }^{\text {Some }}$ native fish, such as the salmon that Europeans knew from their own ports, were represented silvery in their plates. Similarly, the goldfish, an early import to Europe from Asia known for its brightness and decorative potential, was depicted as bright orange. Serving as pets in China from the $\mathrm{Wu}$ dynasty, Mediterranean countries had bred the animals — presumably for garden ponds — as early as $1770 .{ }^{67}$ Yet, these "native" fish were the exception in color and aesthetic portrayal. In contrast, foreign fish, which could only reach naturalists in dried or preserved form, were the ones that Bloch saw and reinserted into the European waterscape, taxonomizing the coral reef vertebrates as common salt or freshwater fishes. The Amphiprion ephippium (Figure 2), part of Bloch's private "wet- 
collection" of specimens, depicted a round and fleshy being with light accents behind the lateral fin, a large head in shades of grey, beige, and black, dabbed in terracotta. Between the coral reef fish, and the bright goldfish, or else the native salmon, differences were clear; the long path of travel for the preserved Chaetodoni and ephippium meant that its coloration did not reach the naturalists' gaze, nor that of the printers of the circulated prints and the handcolored items produced for limited editions.

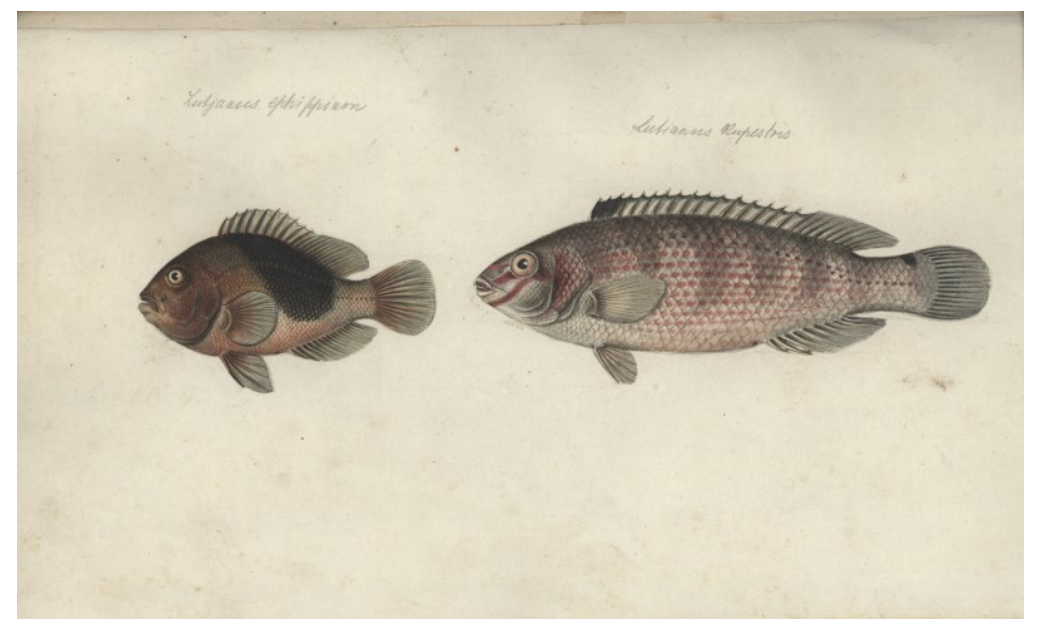

Figure 2. The Amphiprion ephippium (left), taxonomized as a Lutjanus ephippium; and Lutjanus Rupestris [sic] (right). Marcus Elieser Bloch, Naturgeschichte der ausländischen Fische, Vierter Theil, Berlin 1790, Lutjanus Euphippium: Taf. CCL (Fig. 2). Courtesy of Humboldt University, Berlin.

Foreign fishes such as the polymnus and ephippium, being dried and preserved, could fit comfortably into the naturalists' worldview of a dark and dreary underwater world. The silver salmons and the goldfish represented exceptions to nature, rather than the norms of the deep. Both Linnaeus and Bloch placed two Amphiprions in the genus of popular European edible fishes. Linnaeus named the creature a Perca, a saltwater perch, highlighting the "thorny cover" of its body to make his case ${ }^{68}$ To Bloch, the Amphiprion 
ephippium was a Lutjanus, a freshwater snapper which, despite its aggressive, carnivorous behavior, served well as food.

Linnaeus' discussions of fish are generally short, only a few lines in the presumably mezzotint printed volume, and include no images, in line with the classic tradition to avoid representations for fear of creating a larger margin of error for copiers. ${ }^{69}$ Bloch's depiction of the Amphiprion allows more room for interpretation, showing some evidence that the scientist filled gaps of information with knowledge of familiar European waters. ${ }^{70}$ Bloch had not travelled to India; the image in his work thus depicts the influence of the study of his own immediate surroundings as he read fish bodies: the European waterscape. Bloch studied the marine fauna of Europe in great detail, and his representation of the Amphiprion resembles a European freshwater fish, rather than a coral reef vertebrate. The dark and muddied colors, stemming from and feeding into the image of the space where light was dull and color barely perceivable, render the depiction a site of perception and projection of, and for, a dark oceanic environment. The Chaetodons collare and annularius in his work, similarly, tend more towards the silver of the salmon or the muted orange of the goldfish. The naturalist's eye could not but integrate the foreign animal into the known natural world of cold and murky river waters, working by difference and similarity to construct an interpretation of the newly inventoried creature. ${ }^{71}$ Bloch's representation, modeling a hypothetically living foreign fish on the basis of a deceased specimen, produced an estimate, and at the same time perpetuated accepted ideas of fish. When revived, the Amphiprion's expression was one of surprise, fitting for an insensible and unfeeling creature. ${ }^{72}$ Next to the second 
Lutjanus, the Rupestris (Figure 2 above), both fishes could well have been fresh or saltwater European fish, rather than foreign specimens.

Technology versus Theory: Representation

From the mid-1820s, descriptions and representations of fish in ichthyologic works authored in Europe display significant changes. Naturalists no longer relied only on their own fishermen and crew, remaining close to the ships and avoiding much contact with the foreign land, but instead began to venture into the water themselves, to collect, draw, and dissect. Neither afraid of the local population nor hesitant to rely on their knowledge, their contact no longer remained limited to the most decrepit of dead creatures, but now incorporated "fresh" and "wholesome" fish, as contemporaries referred to them, that could be either eaten or admired. This shift in attitudes towards the foreign and towards local or native knowledge, as well as in ichthyologic culture, enabled naturalists to come close enough to the foreign fishes to appreciate their beauty as pleasant rather than threatening. Both collectors and naturalists began to see beauty in their objects of studya paradoxical phenomenon in a sense, where previous knowledge and depictions of fish combined with a novel, romantic attitude towards nature.

It must be recognized at this point that various phenomena coincided in the early decades of the nineteenth century that may also have contributed to reforming the view of fish. Arguably, technological change and improvements in printing with a higher degree of color played their part; however, the significance of aquatint and lithography must not be overemphasized. Studies dated as early as Ray and Willoughby's 1686 Historia Piscium included vibrant colored plates before technology made this easier and cheaper; 
the 1686 work cost a fortune, and famously sabotaged the printing of Newton's Principia.${ }^{73}$ Louis Renard's 1719 History of Sea Curiosities similarly prided images in bright illustrations. ${ }^{74}$ These works, however, did not affect European understandings of fishes' nature. They remained "curiosities," oxymoronic, contradictory creatures, not representative of the sea, but out of the norm—-beautiful monsters with pointy teeth. ${ }^{75}$

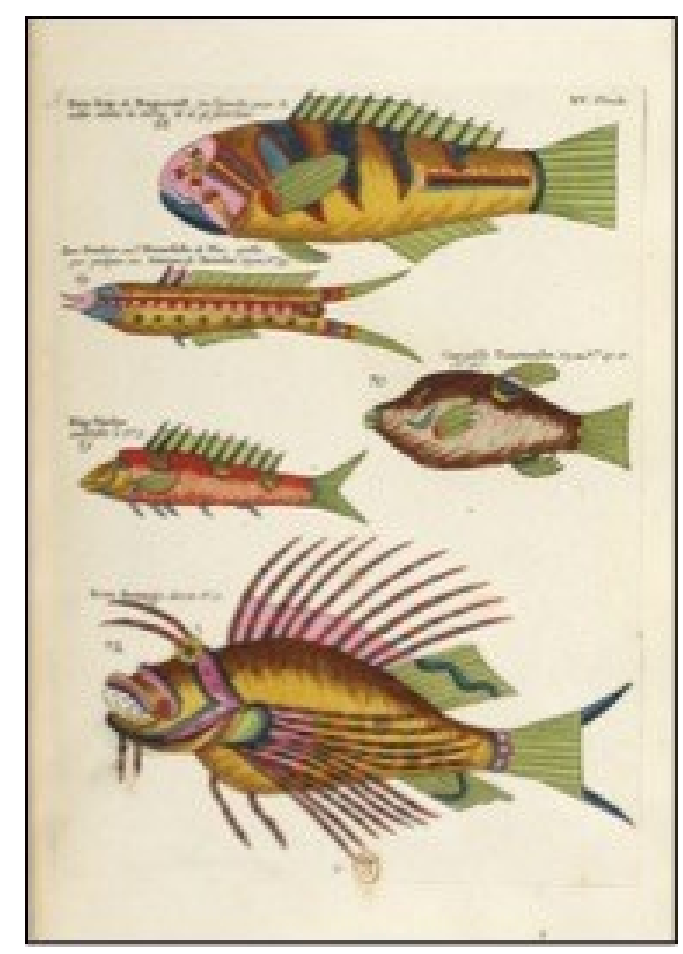

Figure 3. More “curiositez” [sic] from the Indies, 1719. Louis Renard, Poissons, écrevisses et crabes de diverses couleurs et figures extraordinaires que l'on trouve autour des îles Moluques et sur les côtes des terres australes, (1719), mark 30:78. Public Domain.

Apart from the technology—notably lithography at the turn of the century—and travel, we must highlight romanticism, with its shifting attitude towards nature, and contemporary aesthetics informing naturalists sensibilities as key contributors to the knowledge-making enterprise during the Second Scientific Revolution. Daston and 
Galison have defined "objectivity" as a modern disciplining ethics, a way of seeing after $1860 .{ }^{76}$ In the preceding era, the Second Scientific Revolution, aesthetic theory played a central role in guiding and informing ichthyologists' experience and encounters with nature ${ }^{77}$ In this frame of reference, or literal worldview, scientists saw nature as full of beauty, with foreign fishes forming a part of it. Ichthyology benefitted from the reciprocal relationship between aesthetic theory and natural history before a rearrangement of epistemologies after 1860, and the professionalization and stratification of disciplines. ${ }^{78}$

With these new ways of seeing inspired by Immanuel Kant, Friedrich Schiller, and Friedrich Schelling, as well as poets and artists like Friedrich Hölderlin and Caspar David Friedrich, theorists and ichthyologists redeemed inert matter as limiting and sabotaging — an idea persistent since René Descartes— to become a site of sublime experience. ${ }^{79}$ Symptomatic of a wider cultural change in Western Europe, aesthetic theory allowed ichthyologists to see, taxonomize, describe and represent foreign fishes as a coherent part of an aesthetic natural world. Note the following ideas in an ichthyologic study by Swainson, combining aesthetic appreciation of nature with the pursuit of truth:

...it is by her .... gay adornments, — her ...shape and colour, that Nature allures the eye of man; while she draws him on to the ...noble pursuit of her hidden analogies... [the naturalist aims to see and] to invest general truths with a sort of majesty, as well as of beauty; so that, at length, this new charm rivals and prevails over the graces and attractions of external diversity, and imparts more and more force and advantage to that which is 
occult, until it quite overpowers that which is superficial. Thus it is, that in the course of philosophical pursuits, abstract principles come forth more and more into the light, stand out with greater distinctness before the mind; and ere long, ...in the hour of relaxation...the rational faculty...contemplates with open eye all that is great and permanent. ${ }^{80}$

It was the external that indicates the interior, yet a recognition of beauty that facilitated a reinterpretation of matter's inner value and the natural order of things. Swainson bridged aesthetic theory with the a priori and brought it to bear on ichthyologic study: the mind's faculties "at play" saw nature's beauty and recognized its true meaning. ${ }^{81}$ In this thought, as in scientific practice, the dividing line between art and science dissolved: just as for the artist in the romantic conception of art as metaphysics, "creative activity was part of the general activity by which the subject create[d] its entire world," 82 for ichthyologists like Swainson, "aesthetic experience" served as "the criterion, instrument, and medium of awareness of ultimate reality of the absolute." 83 Knight has called Swainson a romantic, and in his attitudes towards beauty in science, Swainson was not alone. ${ }^{84}$

German traveler and explorer to northern Africa and the Red Sea Eduard von Rüppell (1794-1884) arguably marked a turning point in terms of perception in the late 1820s. In Rüppell's account, the small Amphiprion bicinctus was a “juice-brown” fish, with two "sky-blue (himmelblauen) vertical stripes, each with a black setting" and "fins of an ochre-yellow color." ${ }^{\text {" } 5}$ (Figure 4). Rüppell apparently only studied fresh specimens, describing his travels and dwellings by the side of the Nile in the 1820 s and his interactions with local fishermen; his estate at the University of Frankfurt includes no 
preserved specimens. ${ }^{86}$ Rüppell's travels brought him closer to his object of study, and he edged nearer to it in its fresh state; the resulting representation swam at the threshold of transition.

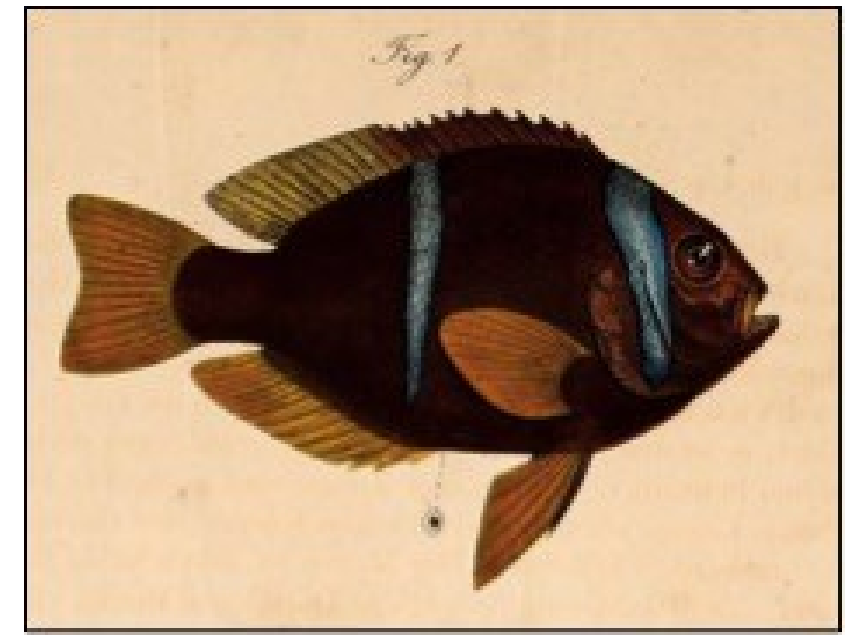

Figure 4. Eduard von Rüppell's Amphiprion bicintus, 1828. Rüppel, Fortsetzung der Beschreibung, 138, Plate 35, selection. Public Domain.

After Rüppel, the negative image of fish quickly dissipated. In 1830, seminal collector and taxonomist Baron Georges Cuvier wrote about his Amphiprion chrysogaster:

...this description, based on individuals altered by the liquid, can but give a feeble idea of the beauty of the species. Monsieur Desjardins has only just sent us it from the Isle-de-France in a jar, almost fresh, and on it we can see that the streaks are a beautiful pearl-gray, and the breast and the pair of fins a beautiful golden yellow. ${ }^{87}$ 
Cuvier's awareness of the effect of death on beauty was key. Though not a traveller himself, Cuvier was located at the nexus of a collecting network spanning the globe and highly aware of the changes in his object of study after death ${ }^{88}$ Cuvier described the specimen using value-laden words: "pearl" grey and "golden" yellow. He classified two Amphiprions as the "golden belly" and "golden fin" (chrysogaster and chrysoptera), marking a shift from the previous practices of Linnaeus and Bloch. Cuvier wrote that to study a preserved specimen "either dried or in preservative" was limited, as "the colors... are almost always misleading in subtle ways because there is no art that can preserve colors after death." ${ }^{89}$ Naturalists had not only become aware of the effects of death, but separated out manifestations of death from the accounts of their specimen of study, and the living original that they did not see..$^{90}$

The contemporary cultural trend of enjoying nature, and studying it as a pastime, influenced naturalists such as John Whitchurch Bennett (1808-1843) who prioritized the aesthetic nature of foreign fishes. While spending several years on Ceylon (1816-1827), Bennett compiled the Selection from the most remarkable and interesting fishes found on the Coast of Ceylon alongside his illustrator Clark with a true interest in the aesthetic. ${ }^{91}$ To Bennett, ichthyology was also a leisurely activity, and his illustrated work served as an aesthetic product for middling- or upper-class consumers, as well as a reference work for naturalists. ${ }^{92}$ While naturalists had presumably outsourced such tasks as stuffing fish to others whenever possible, naturalists like Bennett could enjoy drawing beautiful fishes as a class-appropriate activity on site. Sketching in regular interaction with local fishermen, Bennett's work not only displayed fish as aesthetically pleasing, but his descriptive language incorporated semantics referring to precious signifiers. He described 
the scales of the Holocentrus Ruber as "tinged with gold," the Scomber Heberi, in turn, as "silvery, shot with gold." "93 "Bright yellow," "bright red," and "bright blue," make appearances in his descriptions. ${ }^{94}$ Bennett further included "native" accounts and the names of the species in local writing.

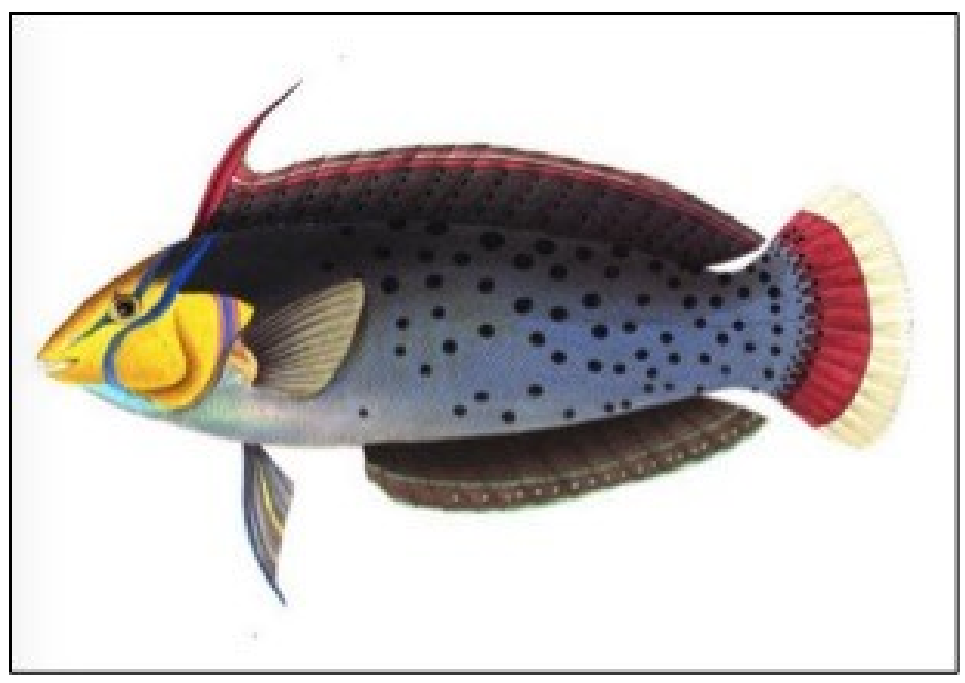

Figure 5. Representation of the Balistes Biaculeatus. Bennett, A selection, section 15. Public Domain.

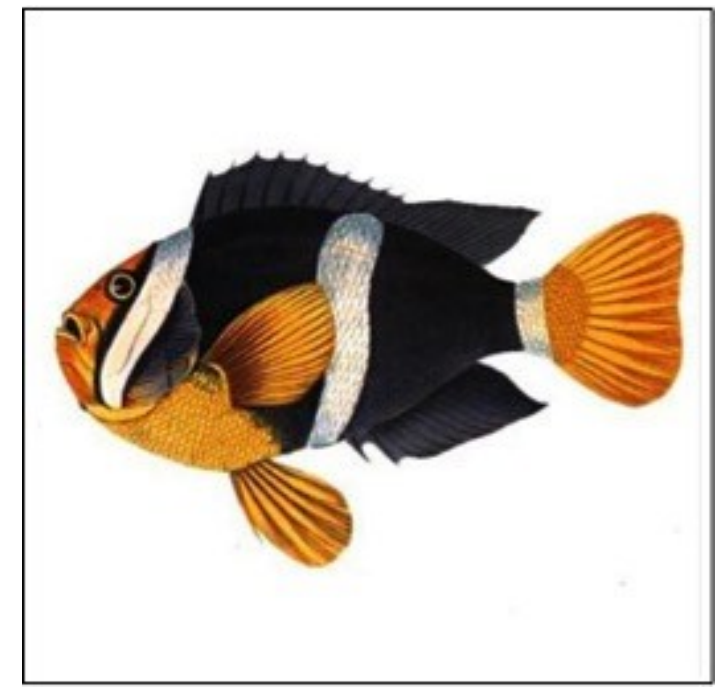

Figure 6. Amphiprion clarkii (original name: Anthias clarkii).

Bennett, A selection, section 28. Public Domain. 
Bennett named the Anthias clarkii (Figure 6) in dedication and thanks to his professional illustrator, demonstrating the importance of the aesthetic. His focus on the fish's appearance, his detailed discussion of the colors of the fish, and the rich plates of his treatise stand for a different phase and marked a point in the reconception of fish as aesthetically pleasing creatures. Bennett's discussion of the $A$. clarkii reads:

Body dark purple, approaching to black, divided by three white streaks...Part of the head, the body between the pectoral and ventral fins, and the caudal fin, are bright yellow, tinged with orange; the dorsal and anal fins are purple. Mouth situated high, the iris golden. ${ }^{95}$

The presence of light, as well as the experience of observing and studying the fish in the luminous surroundings of the Indian Ocean, modified the representation of foreign fishes. Bennett highlighted the complex hues of the darker parts of the specimen's body, calling them purple rather than a pure black. By making the Ceylon marketplace his laboratory, Bennett optimized his conditions for an aesthetic experience, maximizing the light to reveal color nuances, otherwise more difficult to perceive. Furthermore, note that while Rüppell's A. Bicinctus still shows pointy teeth, Bennett's A. clarkii lacks any. His Balistes Biaculeatus may even be smiling.

As of mid-century, several natural philosophers succeeded in preparing the first stable aquariums; from 1856 in Britain and 1860 in Germany, aquariums decorated homes and provided educational spectacles in urban centers. ${ }^{96}$ A French explorer carried 
out the first underwater walk with a breathing apparatus, and one would suppose, ichthyology would never be the same. ${ }^{97}$ Yet, again, it was neither technology nor printing that made the greatest difference. Given the professional knowledge that saltwater aquariums required, or the patriotic stance that "the humble-colored" fishes of Germany were "their countrymen," most home aquariums held freshwater creatures, such as insects, worms, and polyps, that were not necessarily praised for their aesthetic value. ${ }^{98}$ In the meantime, exploratory travels shifted their focus to the African continent and Arctic passages, diverting the scientists' eye away from saltwater fishes until well into the twentieth century. Fears of the sea did not entirely dissipate in Jules Verne's imaginings of the deep ocean, and tales of sea-monsters persisted well into the twentieth century. ${ }^{99}$ Until underwater photography, domestic saltwater aquariums, and scuba diving became popularized in the twentieth century, naturalists' travel and their publications had to serve as the primary communicators of foreign fishes' beauty. Breevort, studying the Amphiprion frenatus in 1856, for example, though using a specimen in alcohol, emphasized that "the colour of this species, as preserved in alcohol, is very different from that of the living fish." ${ }^{\prime 100}$ Philip Henry Gosse, the naturalist who popularized the aquarium in Britain, even suggested in 1856 that the observation of a living fish in a water tank "make us acquainted rather with an individual than with a species," denoting a recognition of individuality in his aquarium-dweller, a profound shift in scientific perception. ${ }^{101}$

Historians of science, medicine and technology for the last forty-odd years have questioned the particular paths that knowledge has pursued over the past centuries, and pointed to the alternative paths that they might have taken if it had not been for particular 
circumstantial, personal, or political settings. ${ }^{102}$ Historians of natural history and botany tell the story of the gendering of nature through the exploration of a "subjective," scientific "eye" self-described as masculine, as rationality found its incarnation in specific white, male bodies. ${ }^{103}$ Ichthyologists' recognition during the Second Scientific Revolution of a subject's a priori capacity to see beauty as a valuable contributor to knowledge highlights the reciprocal relationship between worldviews, worldviewers, and scopes of experience in pre-objective science. Ichthyologists used aesthetic theory and a Romantic conception of beauty as truth in nature to access, select, and portray scientific truth.

Daston and Galison's insistence that pre-objective science was not "romantic" was necessary to make a point about the rationality of aesthetic viewing as an integral part of pre-objective science; however, the very view that romanticism and romantic science were other than scientific is itself historically bound up in our own epistemology, which retroactively distinguishes between what had belonged together in naturalist activity beforehand: the subject and the object, the a priori and nature, aesthetics and knowledge. Much scholarship has shown the deep connections between early-nineteenth century Romantics and Darwin, or, as here, the indivisibility of art and science, historicizing the artificial line between science and art. ${ }^{104}$ It is this article's purpose to contribute to this project and note, as many have before, that it is possible to retrospectively over-prune the "Tree of Knowledge," given that a variety of epistemologies have historically formed an integral part of the intellectual enterprise. ${ }^{105}$ Epistemology continues to warrant interdisciplinary attention, as the including and excluding of ways of knowing and seeing in the histories of science and medicine 
connect directly to political inclusion. By drawing attention to embodied rationality, rather than epistemology, post-objective science forced various subjectivities to hide, acting as a form of violence that disciplined subjects were trained to self-inflict, that excluded not only formerly legitimate ways of seeing, but also ways of being it defined as less than rational. ${ }^{106}$ Selective epistemology, in essence, was political exclusion by proxy, as the "new identity regime" of the modern era described by Dror Wahrman encoded rationality selectively on only some "bodies." ${ }^{107}$ While social hierarchy was anything but new, novel was that scientific objectivity buttressed selective political enfranchisement by untenably equating the allegedly rational body with its undoubtedly rational views, with lasting political repercussions until the present.

\section{Conclusion}

In the history of Ichthyology between the late eighteenth century and the $1830 \mathrm{~s}$, aesthetic ways of seeing informed and enriched ichthyologists' studies of foreign fishes. Travel expanded the naturalists' realm of experience, and technological change could help visually represent novel attitudes towards nature. Key was an underlying theoretical shift at the ontological level that changed the naturalist's eye/I, reading matter as infinite, and beauty as an indicator of truth. This aesthetic redefined nature as a sublime site and integrated beautiful foreign fishes into it. Alongside technological innovation and travel, this way of seeing changed the attitude of naturalists and Europeans more largely to foreign fishes as part of the larger development to approach nature as the quintessential locus of beauty, and the human subject as the entity whose purpose it was to observe it. 
I thank Brian Vick, Sander Gilman, Elena Conis, and Laura Otis for their time and encouragement during writing, as well as Alistair Sponsel and Denise Phillips for feedback during revision. Further acknowledgements go to Emory University's History Department, its European History Workshop, particularly Cassandra Casias and Rebekah Ramsay, the Fritz-Thyssen Foundation and the Gotha Research Center of the University of Erfurt.

${ }^{1}$ Immanuel Kant, Critique of Judgment, ed. Werner S. Pluhar (Indianapolis: Hackett, 1987), 99.

${ }^{2}$ Helen M. Rozwadowski, Fathoming the Ocean: The Discovery and Exploration of the Deep Sea (Cambridge: Harvard UP, 2005), 37.

${ }^{3}$ William Greatheed Lewis, A Catechism of Ichthyology: Or, The Natural History of Fishes; on a New Plan, Illustrated with Engravings. To Which is Added, an Etymological and Pronouncing Vocabulary of the Technical Terms (London: Dolby, 1825), 7 and 31, respectively.

${ }^{4}$ Marcus Elieser Bloch, Allgemeine Naturgeschichte der Fische: Naturgeschichte der ausländischen Fische (Berlin: Realschule, 1785).

${ }^{5}$ Lorraine Daston and Peter Galison, Objectivity (New York: Zone, 2007), 58.

6 Andrew Cunningham and Nicholas Jardine, "Introduction: The Age of Reflexion," Romanticism and the Sciences, ed. Andrew Cunningham and Nicholas Jardine (Cambridge: CUP, 1990), 1.

${ }^{7}$ Daston and Galison, Objectivity, 98.

${ }^{8}$ Daston and Galison, Objectivity, 104. 
${ }^{9}$ William Swainson, On the Natural History and Classification of Fishes, Amphibians and Reptiles (London: Longman, Brown, Green, and Longmans, 1839), 7071.

${ }^{10}$ Robert McCracken Peck, "Preserving Nature for Study and Display," in Stuffing Birds, Pressing Plants, Shaping Knowledge: Natural History in North America 1730-1860, ed. Sue Ann Prince, (Philadelphia: APS, 2003), 14; Peck, “Alcohol and Arsenic," 34; David Elliston Allen, The Naturalist in Britain: A Social History (Princeton: Princeton UP, 1976), 26, 32.

${ }^{11}$ Collection "crazes" turned to ocean creatures around 1800 but largely excluded fishes. Allen, The Naturalist in Britain, 112, 126; Peck, "Preserving Nature," 14-16.

${ }^{12}$ Laura Otis, Müller's Lab (Oxford: OUP, 2007), xi. Robert McCracken Peck, “Alcohol and Arsenic, Pepper and Pitch: Brief Histories of Preservation Techniques," in Stuffing Birds, Pressing Plants, Shaping Knowledge: Natural History in North America 1730-1860, ed. Sue Ann Prince (Philadelphia: APS, 2003), 34, 36; Glyndwr Williams, Naturalists at Sea: Scientific Travellers from Dampier to Darwin (New Haven: Yale UP, 2013), 6 .

13 Swainson, in Peck, "Alcohol and Arsenic," 34.

${ }^{14}$ Many agents remain barely visible: ships' crew members, fishers, market vendors and other guiding natives, artists and engravers, printers, and wider audiences of ichthyologic monographs. On the mutually constitutive nature of art and science in Central Europe between 1780-1830 and wider inclusion in scientific activities see: Denise Phillips, Acolytes of Nature: Defining Natural Science in Germany, 1770-1850 (Chicago: Chicago UP, 2012). 
${ }^{15}$ Daston and Galison, Objectivity, 64.

${ }^{16}$ Michael Twyman, Printing, 1770-1970: An Illustrated History of Its

Development and Uses in England (London: Eyre \& Spottiswoode, 1970), 37.

${ }^{17}$ Twyman, Printing 39-47.

${ }^{18}$ Carolyn Korsmeyer, Making Sense of Taste: Food and Philosophy (New York: Cornell UP, 1999), 26-27. For Schiller, developing Kantian ontology, beauty reconciled life and form, spirit and nature. Friedrich Schiller, Letters on the Aesthetic Education of Man, ed. Walter Hinderer and Daniel O. Dahlstrom (New York: Continuum, 1993), 1178, 121, 126-7, 128, 129. Friedrich Schelling, "On the Relationship of the Plastic Arts to Nature," in The True Voice of Feeling: Studies in English Romantic Poetry, ed. Herbert Read (New York: Pantheon Books, 1953), 324, 329, 331, 339, 334. Further, Hans J. Schmitt, and Otto F. Best, eds. Die deutsche Literatur in Text und Darstellung. Romantik I. vol. 8 of 16 (Stuttgart: Reclam, 1974), 57. Rosenkranz challenged this aesthetic in 1853: Karl Rosenkranz, Aesthetik des Häßlichen (Königsberg: Bornträger, 1853). For British romantic sea-encounters, see: Samuel Baker, Written on the Water: British Romanticism and the Maritime Empire of Culture, (Charlottesville: Virginia UP, 2010); Samuel Taylor Coleridge, The Rime of the Ancient Mariner (London: Clay, 1857), 28.

${ }^{19}$ Daston and Galison, Objectivity, 320.

${ }^{20}$ Robert J. Richards, The Romantic Conception of Life: Science and Philosophy in the Age of Goethe (Chicago: Chicago UP, 2002); David Knight, "Romanticism and the sciences," in Romanticism and the Sciences, ed. Andrew Cunningham and Nicholas Jardine (Cambridge: CUP Archive, 1990), 13-24; Richard Holmes, The Age of Wonder: How the Romantic Generation Discovered the Beauty and Terror of Science (Knopf 
Doubleday, 2009); Noah Heringman, ed., Romantic Science: The Literary Forms of Natural History (Albany: SUNY Press, 2003).

${ }^{21}$ Bernd Brunner, The Ocean at Home: An Illustrated History of the Aquarium (London: Reaktion, 2011).

${ }^{22}$ Alistair Sponsel, Darwin's Evolving Identity: Adventure, Ambition, and the Sin of Speculation (Chicago: Chicago UP, 2018), 18. On romanticism in Darwinian evolution, see: Richards, The Romantic Conception of Life, 513-554.

${ }^{23}$ Otis, Müller's Lab, 14, 41. Exploratory travels were transnational enterprises, naturalists shared a canon of works, agreeing on methods of collection and preservation for study. Harry Liebersohn, The Travelers' World: Europe to the Pacific (Cambridge: Harvard UP, 2006), 7, 116, 123, 309-12.

${ }^{24}$ From the seventeenth century vision "became prioritized over other senses" in scientific pursuits. Sharon Macdonald, "Exhibitions of power and powers of exhibition: An introduction to the politics of display," in The Politics of Display: Museums, Science, Culture, ed. Sharon Macdonald (New York: Routledge, 1998), 7.

${ }^{25}$ On gustation, olfaction and "gentlemanly" laboratory cultures, see: Steven Shapin, "The Sciences of Subjectivity," Social Studies of Science 42, no. 2 (April 1, 2012): 170-84; Steven Shapin, A Social History of Truth: Civility and Science in Seventeenth-Century England (Chicago: Chicago UP, 1995).

${ }^{26}$ Rozwadowski, Fathoming the Ocean, 2.

${ }^{27}$ Daston and Galison, Obectivity, 36 and 48.

${ }^{28}$ Rozwadowski, Fathoming the Ocean, 2 and 12. 
${ }^{29}$ Guillaume Rondelet (1507-1566), Conrad Gessner (1516-1565), Ambroise Paré (1510-1590), Ulisse Aldrovandi (1522-1605), Gaspar Schott (1608-1666); e.g. Ambroise Paré, Oeuvres (Paris: Gabriel Buon, 1585), Ch. LIX, and Conrad Gesner, Historiae Animalium (Zurich: Froschoverum, 1551), De Cetis - Animalium Mar. Also: M. Boesemann, “Collectors and Fish Collections of the Rijksmuseum van Natuurlijke Historie, Leiden," in Collection Building in Ichthyology and Herpetology, ed. Theodore W. Pietsch and William Dewey Anderson (Lawrence: American Society of Ichthyologists and Herpetologists, 1997), 81-87.

${ }^{30}$ Lewis, A Catechism of Ichthyology, 19.

${ }^{31}$ Lewis, A Catechism of Ichthyology, 12.

${ }^{32}$ Lewis, A Catechism of Ichthyology, 9. G. H. Parker, "The Sense of Hearing in Fishes," The American Naturalist 37, no. 435, (March 1, 1903): 185-204, and G. H. Parker, "A Critical Survey of the Sense of Hearing in Fishes," Proceedings of the American Philosophical Society 57, no. 2 (January 1, 1918): 69-98. On contemporary research on the "talkative" Amphiprion polymnus, see: BBC, "7. Our Blue Planet," Blue Planet II, video documentary, 12:38. Also: "Fish Sounds: Do fish talk to each other?", BBC Earth Unplugged, documentary video, 6:46, accessed July 4 2018, https://www.youtube.com/watch?v=POITH02VVrw.

${ }^{33}$ Georg Wilhelm Friedrich Hegel, Philosophy of Nature, vol. 3. of 3 (London: George Allen and Unwin Ltd., 1970), 190.

${ }^{34}$ William Pinnock, A Catechism of Ichthyology: Being a Familiar Introduction to the Natural History of Fishes (London: Whittaker, 1823), 5.

${ }^{35}$ Pinnock, A Catechism of Ichthyology, 9. 
${ }^{36}$ Pinnock, A Catechism of Ichthyology, 4-5, and Lewis, A Catechism of

Ichthyology, 8-9.

${ }^{37}$ Pinnock, A Catechism of Ichthyology, 9.

${ }^{38}$ Glyndwr Williams, Naturalists at Sea : Scientific Travellers from Dampier to

Darwin (New Haven: Yale UP, 2013), 6; Robert McCracken Peck, “Alcohol and

Arsenic," 34.

${ }^{39}$ Rozwadowski, Fathoming the Ocean, 7-8; Barbara E. Brown, "The Legacy of

Professor John Stanley Gardiner Frs to Reef Science," Notes and Records of the Royal

Society of London 61, no. 2 (22 May 2007): 208.

${ }^{40}$ David Elliston Allen, The Naturalist in Britain: A Social History (Princeton:

Princeton UP, 1976), 26 and 32.

${ }^{41}$ Peck, "Preserving Nature," 14; Peck, "Alcohol and Arsenic," 34.

42 Peck, "Preserving Nature," 16.

${ }^{43}$ On "gentlemanly" cultures of research, see: Steven Shapin, A Social History of

Truth: Civility and Science in Seventeenth-Century England (Chicago: University Of

Chicago Press, 1995), e.g. xii, xxx.

${ }^{44}$ John Gribbin, Science: A History (Singapore: Penguin, 2010), 203-206.

${ }^{45}$ Lewis, A Catechism of Ichthyology, 8.

${ }^{46}$ Gribbin, Science, 215.

${ }^{47}$ Robert Henri Gosse, Naturalist Rambles on the Devonshire Coast, (London:

Voorst, 1853).

${ }^{48}$ Williams, Naturalists at Sea, 6. 
${ }^{49}$ Everard Home and John Hunter, "Description of a New Marine Animal. In a Letter from Mr Everard Home, Surgeon, to John Hunter, Esq F.R.S. with a Postscript by Mr. Hunter, Containing Anatomical Remarks upon the Same," Philosophical Transactions of the Royal Society of London 75 (1785): 333.

${ }^{50}$ Home and Hunter, "Description of a New Marine Animal," 335.

${ }^{51}$ Georges Cuvier and Theodore W. Pietsch, Historical Portrait of the Progress of Ichthyology: From Its Origins to Our Own Time (Baltimore: Johns Hopkins UP, 1995), $120-122$.

${ }^{52}$ See also William Swainson, On the natural history and classification of fishes, amphibians and reptiles (London: Longman \& co., 1838); Christine Jackson and Peter Davis, Sir William Jardine: A Life in Natural History (London: Leicester UP, 2001). Further: Marcus Elieser Bloch and Johann Gottlob Schneider, Systema ichthyologiae: iconibus CX illustratum (Berlin: Auctor, 1801); William Pinnock, A catechism of ichthyology (London: Whittaker, 1825).

${ }^{53}$ Lewis, A Catechism of Ichthyology, 17.

${ }^{54}$ Lewis, A Catechism of Ichthyology, 18.

${ }^{55}$ Lewis, A Catechism of Ichthyology, 23.

${ }^{56}$ Cuvier, Historical Portrait, 122. William E. Burns, Science in the Enlightenment: An Encyclopedia (Santa Barbara: ABC-CLIO, 2003), 43.

${ }^{57}$ Cuvier, Historical Portrait, 120-1.

${ }^{58}$ Peck, “Alcohol and Arsenic," 36-8; Alwyne Wheeler, “The Linnaean Fish Collection in the Zoological Museum of the University of Uppsala," Zoological Journal 
of the Linnean Society 103, no.2 (October 1, 1991): 152, e.g. Figure 2; also: Pietsch and Anderson, Collection Building, 61.

${ }^{59}$ Swainson, On the natural history and classification of fishes, 71.

${ }^{60}$ Cuvier, Historical Portrait, 120-1.

${ }^{61}$ See: Amphiprion polymnus, holotype, Figure 16 in Alwyne Wheeler, "The Linnaean Fish Collection in the Zoological Museum of the University of Uppsala,” Zoological Journal of the Linnean Society 103, no. 2 (October 1, 1991): 176.

${ }^{62}$ Swainson, On the natural history and classification of fishes, 70.

${ }^{63}$ E.g.: "Two Common Guitarfish," in Peck, "Alcohol and Arsenic," 37.

${ }^{64}$ Richard Lesser, "Dr. Marcus Elieser Bloch. Ein Jude begründet die moderne Ichthyologie," Das achtzehnte Jahrhundert 23, no. 2 (1999): 238-246.

${ }^{65}$ Markus Elieser Bloch's "wet" collection, now held in Berlin: "Fische," Naturkundemuseum Berlin, accessed July 4 2018, https://www.naturkundemuseum.berlin/de/einblicke/sammlungen/fische. Marcus Elieser Bloch, et al. D. Marcus Elieser Bloch's, Ausübenden Arztes Zu Berlin ... Oeconomische Naturgeschichte Der Fische Deutschlands ... vol. Pt. 1, v. 1, NaN-3, c. 1. (Berlin: Hesse, 1782), 33, 117.

${ }^{66}$ See: Forschungsbiblitohek Gotha (FBG): MAG Math 8o 01071/03.

${ }^{67}$ Brunner, The Ocean at Home, 24.

${ }^{68}$ Caroli Linnaei, Systema naturce per regna tria naturce, secundum classses, ordines, genera,species, vol. 1 (Stockholm: Holmiae, 1758), 291. This preceded Linnaeus' appointment at Uppsala, and his curation of the Crown's dried fish collection. Bo Fernholm and Alwyne Wheeler, "Linnaean Fish Specimens in the Swedish Museum 
of Natural History, Stockholm," Zoological Journal of the Linnean Society 78, no. 3 (July 1, 1983): 202-203.

${ }^{69}$ Linnaei, Systema naturce per regna tria naturce, 291.

${ }^{70}$ Bloch, Naturgeschichte der ausländischen Fische.

${ }^{71}$ Cuvier, Historical Portrait, 137.

72 Peter Heymans, Animality in British Romanticism: The Aesthetics of Species (London: Routledge, 2012), 1.

${ }^{73}$ Sachiko Kusokawa, "The "Historia Piscium" (1686)," Notes and Records of the Royal Society of London 54, no. 2 (May, 2000): 179-197.

${ }^{74}$ Louis Renard, Fishes, Crayfishes, and Crabs: Louis Renard's Natural History of the Rarest Curiosities of the Seas of the Indies, ed. Theodore W. Pietsch (Baltimore: Johns Hopkins UP, 1995).

75 1830-1850 naturalists decided to privilege standardization and normal occurrences over variation, monsters, or irregularities. Daston and Galison, Objectivity, 68.

${ }^{76}$ Wahrman draws on Daston's idea of the cultural "soundbox" underlying discussions about the self and epistemology. Dror Wahrman, The Making of the Modern Self: Identity and Culture in Eighteenth-Century England (New Haven: Yale UP, 2006), 323, xvii.

${ }^{77}$ Daston and Galison, Objectivity, 33, 39-40, 50, 51, 346.

${ }^{78}$ Christine Kenyon Jones, "British Romanticism and Animals," Literature Compass 6, no. 1 (2009): 136-152; David Perkins, Romanticism and Animal Rights, Cambridge studies in Romanticism, 58 (Cambridge: CUP, 2003). 
${ }^{79}$ Schelling even proposed nature as the new "ideal" and "infinite." Friedrich Wilhelm Joseph von Schelling, First Outline of a System of the Philosophy of Nature (Albany: SUNY Press, 2004), 203.

${ }^{80}$ William Swainson, On the Natural History and Classification of Fishes, Amphibians and Reptiles (London: Longman \& co., 1839), 70-71.

${ }^{81}$ Kant, Critique of Judgment, 115.

${ }^{82}$ Beiser, The Romantic Imperative, 74

${ }^{83}$ Beiser, The Romantic Imperative, 73.

${ }^{84}$ Knight, "Romanticism and the sciences," 22.

${ }^{85}$ Eduard von Rüppell, Atlas zu der Reise im Nördlichen Afrika (Frankfurt am Main: Brönner, 1826), 139-140.

${ }^{86}$ Eduard Rüppell, Fortsetzung der Beschreibung und Abbildung mehrerer neuer Fische: im Nil entdeckt (Frankfurt am Main: Brönner, 1832), 3.

${ }^{87}$ Amphiprion chrysogaster: Georges Cuvier, Histoire naturelle des poissons, vol. 5 (Paris: Levraut, 1830), 301. Desjardins corresponded with Cuvier from Mauritius. Marie-Louise Bauchot, Jacques Daget, and Roland Bauchot, "Ichthyology in France at the Beginning of the $19^{\text {th }}$ Century: the Histoire Naturelle des Poissons of Cuvier (17691832) and Valenciennes (1794-1865)," in Pietsch and Anderson, Collection Building, 61. ${ }^{88}$ Cuvier's travels limited themselves to the collections of Europe. Bauchot et al., "Ichthyology in France," 37.

${ }^{89}$ Cuvier, Historical Portrait, 138. Note Lacépède on "silvery" fishes, with eyes "that shine with the sparkle of a small ruby." Bernard Germain de Lacépède, Histoire Naturelle des Poissons, vol. II (Paris: Furne et Cie Librairies-Éditeurs, 1839), 335. 
${ }^{90}$ For contrasting findings, see Leah Aronowsky, "On Drawing Dead Fish.” Environmental History 21, no. 3 (July 1, 2016): 542-51.

${ }^{91}$ Alwyne Wheeler, “J.W. Bennett's Fishes of Ceylon, Dates of Publication from Supplementary Sources with Notes on Copies of the Book, Alleged Original Drawings, and the Author's Specimens," Archives of Natural History 26, no. 1 (1 February 1999): 51-54.

${ }^{92}$ For similar trends in botany, see: Theresa M. Kelley, Clandestine Marriage: Botany and Romantic Culture (Baltimore: Johns Hopkins UP, 2012), 6.

${ }^{93}$ Rohan Pethiyagoda, Ismeth Raheem, and Barry C. Russell, "JW Bennett, His Fish Names and the Dates of Publication of Fishes of Ceylon," Journal of South Asian Natural History 1 (1994): 35; John Whitchurch Bennett, A selection from the most remarkable and interesting fishes found on the Coast of Ceylon (London: Bull, 1830), Sections 4 and 26, unpaginated.

${ }^{94}$ Bennett, A selection, sections 16, 19, and 29, 16, and 8, respectively; no page number.

${ }^{95}$ Bennett, A selection, section 28, unpaginated.

${ }^{96}$ Brunner, The Ocean at Home, 7, 24, 105; B. H. Becker and William Alford Lloyd, Official Handbook to the Royal Aquarium and Summer and Winter Garden: The Description of the Aquarium (London: Royal Aquarium, 1876); London Royal Aquarium, Official Handbook to the Royal Aquarium, Westminster: Description of the Fish and Other Contents of the Tanks (London: Dickens and Evans, 1877).

${ }^{97}$ Philip Henry Gosse, The Aquarium: An Unveiling of the Wonders of the Deep Sea (London: Voorst, 1856), v. 
${ }^{98}$ Emil Adolf Roßmäßler, Das Wasser. Eine Darstellung für gebildete Leser und Leserinnen, 2nd ed. (Leipzig: Brandstetter, 1860), 479.

99 Sherrie Lyons, "Sea Monsters: Myth or Genuine Relic of the Past," in Oceanographic History: The Pacific and Beyond, ed. Keith R. Benson and Philip F. Rehbock (Seattle: Washington UP, 2002), 68-69; Jules Verne, Vingt mille lieues sous les mers. Vol. 1. (Paris: J. Hetzel et Cie, 1869) and Vingt mille lieues sous les mers. Vol. 2. (Paris: J. Hetzel et Cie, 1870).

${ }^{100}$ Francis L. Haws, Narrative of the Expedition of an American Squadron to the China Seas and Japan (Washington: Beverly Tucker, 1856), 11 in Isaac Lea, Charles Girard, E. D. Cope, Theo. Gill, John Cassin, "Descriptions of Eight New Species of Unionidæ, from Georgia, Mississippi, and Texas; Ichthyological Notices...," Proceedings of the Academy of Natural Sciences of Philadelphia 11 (1859): 148.

${ }^{101}$ Gosse, The Aquarium, iv. For a history of Australian ichthyology, see Brian G. Saunders, Discovery of Australia's Fishes: A History of Australian Ichthyology to 1930 (Collingwood: Csiro, 2012).

102 Daston and Galison, Objectivity, 210.

${ }^{103}$ Ludmilla J. Jordanova, Sexual Visions: Images of Gender in Science and Medicine Between the Eighteenth and Twentieth Centuries (Madison: Wisconsin UP, 1993); Kelley, Clandestine Marriage, Christopher Lawrence and Steven Shapin, ed., Science Incarnate: Historical Embodiments of Natural Knowledge (Chicago: Chicago UP, 1998). 
${ }^{104}$ Richards, The Romantic Conception of Life, 513-554, David Knight,

"Romanticism and the sciences," 13-24; Holmes, The Age of Wonder, Heringman, ed., Romantic Science; Sponsel, Darwin's Evolving Identity, 18.

105 Robert Darnton, "Philosophers Trim the Tree of Knowledge: The Epistemological Strategy of the Encyclopédie," in Robert Darnton, The Great Cat Massacre: And Other Episodes in French Cultural History (New York: Basic, 2009), 191-256; Colin Jones, The Great Nation: France from Louis XV to Napoleon 1715-99 (New York: Columbia UP, 2002), 174-77.

${ }^{106}$ Daston and Galison, Objectivity, 174. See also the debate between Marshall Sahlins, How "Natives” Think: About Captain Cook, For Example (Chicago: Chicago UP, 1996), and Gananath Obeyesekere, The Apotheosis of Captain Cook: European Mythmaking in the Pacific (Princeton: Princeton UP, 1997).

${ }^{107}$ Wahrman, The Making of the Modern Self. Further, Lawrence and Shapin, ed., Science Incarnate. 